\title{
MENINGKATKAN HASIL BELAJAR MATEMATIKA SISWA DENGAN MENGGUNAKAN PERMAINAN ULAR TANGGA PADA TINGKAT SEKOLAH MENENGAH PERTAMA
}

\section{(IMPROVING THE RESULT OF LEARNING MATHEMATICS BY USING THE SNAKE LADDER GAME ON THE FIRST GRADER OF JUNIOR HIGH SCHOOL)}

\author{
Andi Irawan ${ }^{1}$, dan Melda Ayu Wardani ${ }^{2}$ \\ Teknologi Pembelajaran Pascasarjana Universitas Negeri Malang \\ SMA Negeri 1 Dampit \\ Email: 'andi.yawa.tep.um@gmail.com,dan²melda.ayu45@gmail.com
}

\begin{abstract}
Abstrak: Matematika sebagai salah satu mata pelajaran disekolah dinilai cukup memegang peranan penting dalam membentuk siswa berkualitas, karena matematika merupakan suatu sarana berpikir untuk mengkaji sesuatu secara logis dan sistematis. Kasus pada Sekolah Menengah Pertama yaitu kurang maksimal dan variatif dalam pembelajaran matematika di kelas, dan Itu semua bisa dilihat dari hasil ulangan tengah semester pertama yang rata-ratanya masih dibawah standar SKBM (Standar Ketuntasan Belajar Minimum) sekolah. dari permasalahan tersebut menggunakan media pembelajaran ular tangga. Media ini merupakan permainan papan untuk semua kalangan yang dimainkan oleh 2 orang atau lebih. Berdasarkan hasil penelitian pada siklus I dapat dilihat bahwa hasil belajar dengan penerapan media pembelajaran ular tangga sudah baik, hal ini terbukti dari hasil belajar siswa telah mencapai $75 \%$, namun prosentase ini belum memenuhi kriteria yang sangat baik. Setelah mendapat pembelajaran pada siklus II, prosentase ini mengalami peningkatan $10 \%$ menjadi $85 \%$ dengan taraf keberhasilan sangat baik. Hal ini menunjukkan bahwa penerapan media ular tangga dapat meningkatkan hasil belajar.
\end{abstract}

Kata Kunci: Media Pembelajaran, Pembelajaran Matematika, Meningkatkan Hasil Belajar.

\begin{abstract}
Mathematics as one of the subjects in all schools are rated quite play an important role in forming grooves students qualified, because math means a liquid thought to examine something logically and systematically. The case at the junior high school apply insufficient and variable in mathematics learning in the classroom, and it can all be seen from the results of a repeat of the first midterm was a standard area still CSML (Complete Standard Minimum Learning) school. of these problems using media learning ladder snakes. This liquid media board game for all walks of life who is played by 2 or more persons. Based on the results of research on cycle I can be seen that the results of the study with application of ladder snake learning media is already good, it is evident from the results of student learning has reached $75 \%$, but the percentage has not met the criteria. After obtaining the learning cycle II, this percentage experienced guardian $10 \%$ to $85 \%$ with degrees of success very well. This indicates that the application of ladder snake media can improve learning outcomes.
\end{abstract}

Keywords: Instructional Media, Learning Math, Improve Learning Results.

\begin{tabular}{|c|c|}
\hline \multirow{2}{*}{\multicolumn{2}{|c|}{ mencerminkan }} \\
\hline & \\
\hline $\begin{array}{l}\text { kemajuan suatu bangsa. Pendidikan adalah } \\
\text { suatu proses dalam rangka mempengaruhi }\end{array}$ & $\begin{array}{l}\text { kemampuannya. Hal ini menggambarkan } \\
\text { bahwa fungsi }\end{array}$ \\
\hline peserta didik supaya mampu menyesuaikan & meningkatkan kesejahteraan, karena orang \\
\hline & \\
\hline dengan demikian & odohan maupun kemiskinan. \\
\hline perubahan dalam dirinya yang & d \\
\hline memungkinkannya untuk berfungsi secara & \\
\hline 3:79). Pendidikan seseorang dapat dilih & \\
\hline $\begin{array}{l}\text { dari kemampuan dan ketrampilan seseorang. } \\
\text { Kemampuan dan keterampilan yang }\end{array}$ & $\begin{array}{l}\text { mbawa semua anak didik kepada } \\
\text { Dalam pendidikan guru merupakan }\end{array}$ \\
\hline $\begin{array}{ll}\text { dimiliki } & \text { seseorang tentu sesuai dengan } \\
\text { tingkat } & \text { pendidikan yang dimilikinya. }\end{array}$ & $\begin{array}{l}\text { yang sangat menentukan } \\
\text { pendidikan. }\end{array}$ \\
\hline
\end{tabular}
Semakin tinggi pendidikan seseorang, maka 
Pelajaran matematika merupakan salah satu pelajaran yang sangat penting bagi bangsa. Belajar matematika bukan hanya sekedar mencari nilai yang tinggi saja, lebih dari itu pelajaran matematika sangat membantu dalam kehidupan keseharian manusia, karena sangat banyak realita di lingkungan masyarakat walaupun terkadang kita tidak menyadarinya. Hal ini terbukti mulai dari pendidikan sekolah dasar sampai sekolah menengah atas pelajaran matematika tidak pernah hilang. Namun terkadang banyak siswa yang takut bahkan ada yang tidak berminat pada pelajaran matematika, dikarena pembelajaran dari guru yang monoton.

Kasus pada sekolah menengah pertama ini. Peneliti memperoleh informasi dari hasil observasi yang dilakukan dengan guru matematika SMP bahwa nilai matematika siswa kelas VII masih terbilang kurang memuaskan.Kelas VII terbagi dalam empat kelas, yaitu kelas VII A, B, C, dan D.Disini peneliti memegang dua kelas yaitu kelas VII A dan kelas VII B keduanya tidak ada perbedaan perlakuan dalam pemberian metode pembelajaran, yaitu masih samasama menggunakan metode konvensional. Namun ada perbedaan yang sangat signifinikan antara keduanya, dimana kelas VII A cenderung terlihat lebih ramai dalam proses kegiatan belajar mengajar, sehingga siswa kurang memperhatikan penjelasan dari guru. Akibatnya, pemahaman dari suatu materi yang telah disampaikan guru kurang dipahami oleh siswa dan hasil akhirnya juga tidak memuaskan. Itu semua bisa dilihat dari hasil ulangan tengah semester pertama yang rata-ratanya masih dibawah standar SKBM (Standar Ketuntasan Belajar Minimum) sekolah, yaitu 70.Dari 30 siswa di kelas VII A maksimal 7 siswa yang mendapat nilai lebih dari atau sama dengan rata-rata kelas.

Dari beberapa permasalahan di atas maka hal yang dapat meningkatkan hasil belajar adalah media pembelajaran. Dalam hal ini peneliti menggunakan media ular tangga, karena media ini familiar di kalangan siswa. Manfaat menggunakan media ular tangga menurut Nurjatmika (2012:104) adalah Permainan ini sngat bermanfaat, melatih kesabaran, selalu belajar kerja sama, mereka mampu berimajinasi, mengingat peraturan, mengasah kemampuan kognitif, melatih kemampuan motorik.

\section{METODE}

Pada penelitian ini menggunakan metode penelitian kualitatif yang berlandaskan pada filsafat pospositivisme, digunakan untuk meneliti pada kondisi yang alamiah (Sugiyono, 2012:9). Pendekatan kualitatif dalam penelitian ini digunakan untuk mengetahui gambaran secara jelas fenomena selama proses pembelajaran berlangsung. Fenomena tersebut adalah situasi kelas dan pemahaman siswa terhadap pelajaran matematika selama proses. Metode kualitatif digunakan untuk menemukan hipotesis, sedangkan metode kuantitatif digunakan untuk menguji hipotesis (Susan stainback, dalam Sugiyono, 2012:27).

Jenis penelitian ini yang digunakan adalah Penelitian Tindakan Kelas (Claasroom Action Research). Penelitian ini bermula dari permasalahan yang timbul dalam kelas, yaitu hasil belajar siswa pada mata pelajaran matematika sebagaian besar belum mencapai KKM. Hal ini dikarenakan proses belajarmengajar terlalu terpusat pada guru. Selain itu siswa cendrung pasif ketika pelajaran berlangsung. Berangkat dari permasalahan tersebut, peneliti ingin memperbaiki proses belajar mengajar sehingga peneliti menggunakan penelitian tindakan kelas.

Penelitian ini dilakukan dalam konteks kelas yang bertujuan memperbaiki praktek pembelajaran dikelas sehingga dapat meningkatkan ketrampilan proses dan hasil belajar siswa. Dalam penelitian tindakan ini, penulis terlibat langsung mulai dari awal sampai berakhirnya proses penelitian. Secara garis besar, penelitian tindakan ini dilakukan mengikuti proses pengkajian yang terdiri dari 4 tahap (Arikunto, dkk 2010:104) yaitu

a. Merencanakan

Rencana tindakan dalam penelitian tindakan kelas disusun berdasarkan masalah yang hendak dipecahkan. Perencanaan 
tindakan dalam penelitian ini meliputi penyusunan skenario.

b. Melaksanakan

Pelaksanaan tindakan penelitian dalam penelitian ini meliputi pelaksanaan skenario pembelajaran yang telah disusun. Pelaksanaan yang merupakan penerapan isi rancangan (Arikunto, dkk, 2010:18).

c. Mengamati

Kegiatan pengamatan berkaitan dengan pengumpulan data dan dilakukan saat pelaksanaan tindakan berlangsung.

\section{d. Merefleksi}

Refleksi dilakukan untuk mengamati kelebihan dan kekurangan dari pelaksanaaan tindakan, dan untuk mengetahui keunggulan pembelajaran matematika dengan menggunakan media pembelajaran ular tangga.

Berikut ini gambar siklus tindakan dalam penelitian sebagai berikut;

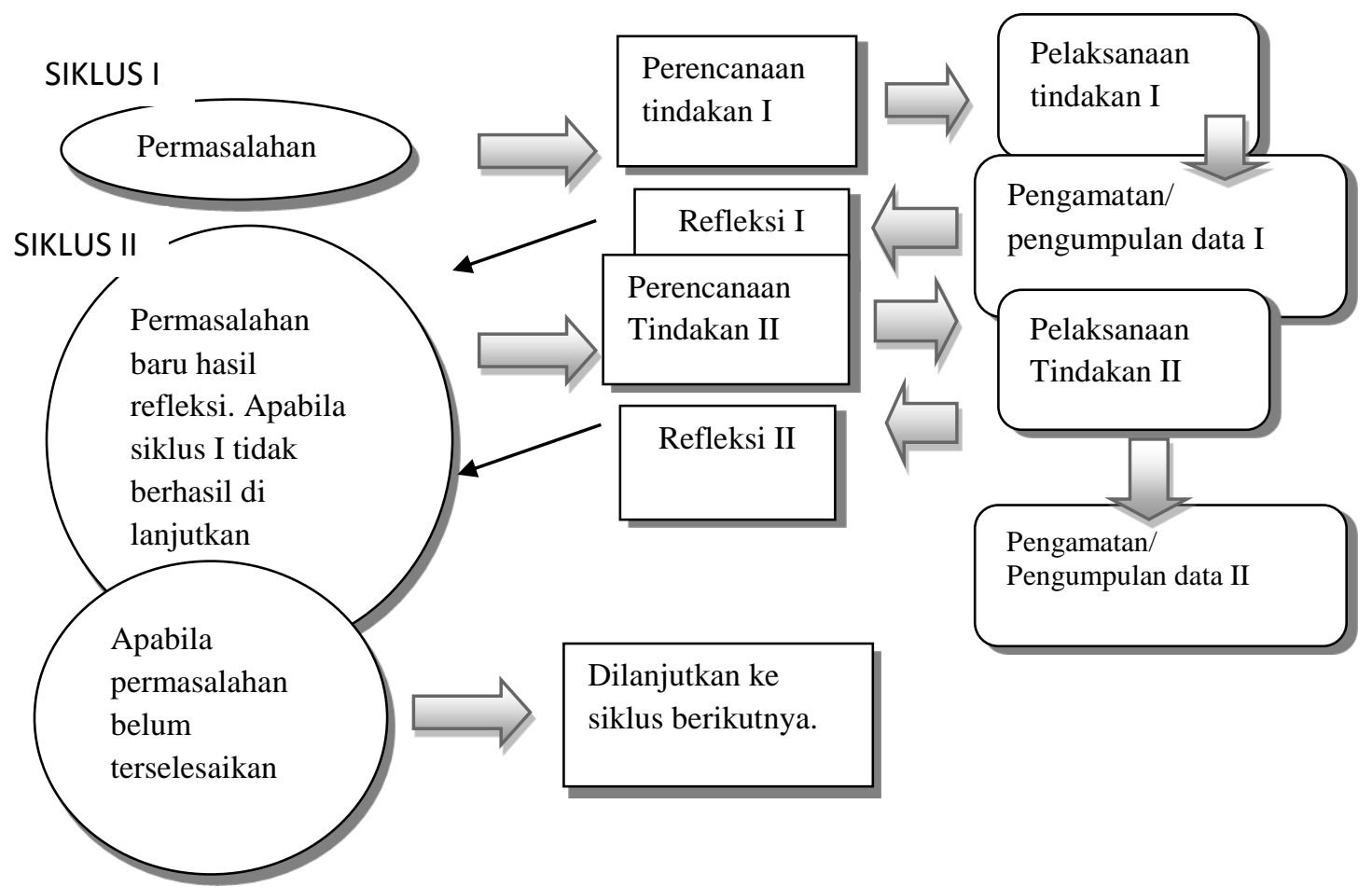

Gambar. Penelitian Tindakan Kelas (Classroom Actioan Research), Arikunto, dkk, 2010:105

\section{HASIL DAN PEMBAHASAN}

Peneliti merencanakan pembelajaran matematika dengan menerapkan media pembelajaran ular tangga. Hal ini dilakukan peneliti untuk meningkatkan hasil belajar siswa kelas VII A SMP tahun pelajaran 2014/2015. Hal ini sejalan dengan teori yang diungkapkan Nur jatmika (2012:104) dalam kelebihan ular tangga yaitu permainan ini sangat bermanfaat, melatih kesabaran, mampu membuat berimajinasi dan mampu mengingat peraturan permainan yang diwujudkan dalam langkah - langkah permainan, mengasah kemampuan kognitif, melatih kemampuan motorik. Hasil ketertarikan siswa dari observasi aktivitas siswa dapat terlihat dalam tabel berikut: 


\begin{tabular}{|c|c|c|}
\hline & Siklus I & Siklus II \\
\hline Guru & $85,4 \%$ & $91,7 \%$ \\
\hline Siswa & $68,1 \%$ & $90,9 \%$ \\
\hline
\end{tabular}

Tabel Rata - Rata Hasil Belajar Siswa dan Ketuntasan Klasikalnya

\begin{tabular}{|l|l|l|l|l|l|l|}
\hline \multirow{2}{*}{} & \multicolumn{2}{|l|}{ Pra - tindakan } & \multicolumn{2}{l|}{ Siklus I } & \multicolumn{2}{l|}{ Siklus II } \\
\cline { 2 - 7 } & Rata - rata & kriteria & Rata - rata & kriteria & Rata - rata & kriteria \\
\hline Hasil belajar & 42,5 & kurang & 71 & baik & 74,6 & Baik \\
\hline $\begin{array}{l}\text { Banyak } \\
\text { siswa yang } \\
\text { tuntas belejar }\end{array}$ & $21,4 \%$ & kurang & $75 \%$ & baik & $85 \%$ & $\begin{array}{l}\text { Baik } \\
\text { sekali }\end{array}$ \\
\hline
\end{tabular}

Tabel Rata - Rata Hasil Belajar Siswa

\begin{tabular}{|c|c|}
\hline & Rata - rata \\
\hline Pra - Tindakan & 42,5 \\
& \\
\hline Siklus I & 71 \\
\hline Siklus II & 74,6 \\
\hline
\end{tabular}

Tabel Ketuntasan Klasikal setiap siklus

\begin{tabular}{|l|l|}
\hline & Rata - rata \\
\hline Pra - Tindakan & $21,4 \%$ \\
\hline Siklus I & \\
\hline Siklus II & $75 \%$ \\
\hline
\end{tabular}

Hal yang perlu diperhatikan peneliti adalah keinginan siswa dalam membaca materi sebelumnya sangat kurang. Dimana kelas VII A cenderung terlihat lebih ramai dalam proses kegiatan belajar mengajar, sehingga siswa kurang memperhatikan penjelasan dari guru. Akibatnya, pemahaman dari suatu materi yang telah disampaikan guru kurang dipahami oleh siswa dan hasil akhirnya juga tidak memuaskan

Dari kenyataan di atas, peneliti merencanakan pembelajaran matematika dengan menerapkan media pembelajaran ular tangga yang terdiri dari tahap mereview, pengelompokkan, kerja mandiri, serta penugasan. Dari empat tahap tersebut dapat ditarik kesimpulan bahwa penerapan media pembelajaran ular tangga dapat meningkatkan hasil belajar siswa

Adapun hasil analisis data penerapan media pembelajaran ular tangga dalam penelitian ini, dapat diuraikan sebagai berikut:

1) Hasil Belajar Siswa

Berdasarkan deskripsi penelitian mengenai hasil belajar siswa, dapat dikatakan bahwa ketuntasan belajar siswa sudah tercapai, karena terdapat $85 \%$ siswa dalam kelas yang mendapat skor lebih atau sama dengan kriteria keberhasilan sangat baik. Hal ini sesuai dengan pendapat Djamarah dan Zain, (2010:107) apabila sebagian besar $(76 \%$ samapai dengan 99\%) bahan pelajaran yang di ajarkan dapat dikuasai oleh siswa memenuhi kriteria baik sekali atau optimal. 
Berdasarkan hasil penelitian pada siklus I dapat dilihat bahwa hasil belajar dengan penerapan media pembelajaran ular tangga sudah baik, hal ini terbukti dari hasil belajar siswa telah mencapai $75 \%$, namun prosentase ini belum memenuhi kriteria yang sangat baik. Setelah mendapat pembelajaran pada siklus II, prosentase ini mengalami peningkatan $10 \%$ menjadi $85 \%$ dengan taraf keberhasilan sangat baik. Hal ini menunjukkan bahwa penerapan media ular tangga dapat meningkatkan hasil belajar.

2) Kegiatan Guru dalam Menerapkan Media Pembelajaran ular tangga

Kegiatan guru dalam menerapkan media pembelajaran ular tangga dibagi dalam lima tahap, dengan pelaksanaan pembelajaran dalam kelas dipersingkat menjadi empat tahap. Adapun tahap pertama dari media pembelajaran ular tangga ini adalah mereview, dalam kegiatan ini peneliti memberikan semangat, menyampaikan tujuan pembelajaran, dan merangsang pengetahuan siswa pada materi persamaan linear satu variabel. Penyampaian semangat ini dimaksudkan agar siswa memiliki dorongan dan semangat dalam belajar, hal ini sejalan dengan pendapat Sardiman (2007:74) yang mengungkapkan bahwa motivasi merupakan serangkaian usaha untuk menyediakan kondisi-kondisi tertentu, sehingga seseorang mau dan ingin melakukan sesuatu. Jika siswa sudah memiliki motivasi maka siswa akan melakukan kegiatan belajar dengan baik.

Penyampaian tujuan pembelajaran dimaksudkan agar siswa mengetahui apa yang akan mereka pelajari sehingga siswa dapat menfokuskan perhatiannya pada materi yang akan disampaikan peneliti. Hal ini sesuai dengan pendapat Slameto, (2013:92) dengan tujuan yang jelas siswa akan belajar lebih tekun, lebih giat dan bersemangat.

Sebelum melakukan tahap kedua dari permainan media pembelajaran ular tangga, peneliti merangsang pengetahuan siswa pada materi persamaan linear satu variabel dengan maksud menyegarkan ingatan siswa pada materi tersebut, karena materi tersebut erat kaitannya dengan materi yang akan dipelajari.

Pada tahap selanjutnya siswa menerima pengelompokkan permainan untuk mempelajarai materi persamaan linear satu variabel yaitu menghitung nilai varibel, dengan pembentukan kelompok yang heterogen. Hal ini sejalan dengan pendapat Abdurrahman dan Bintoro (2000:78) yang mengatakan bahwa kelompok belajar sebaiknya heterogen, baik dalam kemampuan akademik, jenis kelamin, ras, etnik, dan sebagainya sehingga dapat saling mengetahui siapa yang memerlukan bantuan dan siapa yang dapat memberikan bantuan.

Tahap terakhir dari pembelajaran ular tangga adalah penugasan. Dalam hal ini peneliti memberikan arahan kepada siswa untuk membaca materi yang telah dipelajari atau materi yang akan dipelajari serta memberikan pekerjaan rumah agar siswa lebih terampil dalam menyelesaikan soal dan bertanggungjawab dengan tugas yang diberikan peneliti.

Dari hasil keseluruhan pengamatan yang dilakukan, pada siklus I sudah mencapai $75 \%$ yang berarti sangat baik. Sedangkan pada siklus II sudah mencapai $85 \%$ yang berarti sangat baik. Pada siklus I pembelajaran yang dilakukan peneliti sudah bagus, tapi masih ada beberapa kekurangan yang dilakukan peneliti, seperti: Peneliti masih kurang mampu mengkondisikan siswa yang berbuat gaduh atau ramai. Peneliti kurang mampu merangsang siswa agar aktif bertanya dan diskusi. Namun, pada siklus II peneliti sudah mampu mengkondisikan siswa sehingga proses belajar mengajar berjalan lancar.

3) Kegiatan Siswa dengan Media Pembelajaran Ular Tangga 
Kegiatan siswa dalam menerapkan media pembelajaran ular tangga dengan menerapkan indikator-indikator dari pembelajaran ular tangga. Dari hasil keseluruhan pengamatan yang dilakukan pada siklus I penerapan media pembelajaran ular tangga untuk siswa telah mencapai $64,2 \%$ yang berarti baik, namun pada siklus II penerapan strategi pembelajaran media pembelajaran ular tangga untuk siswa sudah mencapai 78,5\% yang berarti sangat baik. Dari data ini dapat diketahui bahwa hampir seluruh siswa sudah menjalankan indikator yang disiapkan peneliti.

Hal ini menunjukkan bahwa kegiatan siswa pada penerapan media pembelajaran ular tangga telah berhasil dengan sangat baik. Dengan menggunakan media pembelajaran ular tangga dapat memancing siswa bertanggungjawab dalam menjalankan tugasnya dan disiplin dalam latihan terkontrol.

\section{KESIMPULAN DAN SARAN}

Kesimpulan

Berdasarkan paparan data dan pembahasan yang diperoleh dari hasil penelitian, maka kesimpulan yang dapat diambil dari penelitian ini adalah sebagai berikut :

Peningkatan hasil belajar matematika siswa dengan menggunakan media pembelajaran ular tangga pada siswa SMP secara umum meliputi kegiatan awal, kegiatan inti, dan kegiatan akhir, sebagai berikut.

\section{a) Kegiatan awal}

Pertama kali yang dilakukan guru adalah mengucapkan salam yang dilanjutkan dengan membaca doa, guru memeriksa kehadiran siswa, guru menyampaikan tujuan pembelajaran yang ingin dicapai pada pertemuan tersebut. Guru melakukan apersepsi yaitu mengaitkan pembelajaran dengan materi persamaan linear satu variabel. b) Kegiatan inti

Pada tahap kegiatan inti, terdapat 3 (empat) langkah kegiatan yaitu:

1) Guru menyampaikan materi secara klasikal

2) Guru membagi siswa menjadi 7 kelompok yang terdiri dari 4-5 siswa yang dikelompokkan secara heterogen.

3) Guru menerapkan media pembelajaran ular tangga

c) Kegiatan akhir

2) Pada tahap akhir guru membimbing siswa untuk menyimpulkan materi yang telah dipelajari.

3) Hasil penerapan media pembelajaran ular tangga menunjukkan peningkatan terhadap keaktifan belajar siswa. Hal ini dapat dilihat dari hasil lembar observasi keaktifan belajar siswa yang menunjukkan peningkatan nilai ratarata persentase tiap indikator. Pada siklus I melalui lembar observasi keaktifan siswa dapat diketahui ratarata persentase sebesar $68,1 \%$ dengan kriteria baik aktif, meningkat pada siklus II menjadi 91,7\% dengan kriteria sangat baik aktif.

4) Hasil penerapan media pembelajaran ular tangga menunjukkan peningkatan terhadap hasil belajar siswa, dalam penelitian ini hasil belajar siswa diukur menggunakan hasil tes yang diberikan setiap akhir siklus. Hasil belajar siswa kelas VII SMP mengalami peningkatan setelah menggunakan media pembelajaran ular tangga. Hal ini ditunjukkan dengan meningkatnya prosentase siswa yang memenuhi KKM dan nilai rata-rata hasil belajar siswa. Pada siklus I prosentase siswa yang memenuhi KKM 75 \% (21 siswa yang tuntas) dengan nilai rata-rata 71 yang memenuhi KKM dan mengalami peningkatan pada siklus II dimana prosentase siswa yang memenuhi KKM dengan persentas sebesar 85\% (24 siswa yang tuntas) dengan nilai rata-rata sebesar 74,6. 
Saran

Berdasarkan uraian simpulan, beberapa saran yang dapat dikemukakan adalah sebagai berikut:

1. Bagi sekolah, untuk memberikan sumbangan pikiran dalam memilih salah satu pembelajaran agar tercipta kegiatan proses belajar mengajar yang lebih aktif pada sekolah tersebut.

2. Bagi guru bidang studi matematika kelas VII A sebagai bahan pertimbangan dalam memilih atau memadukan berbagai strategi pembelajaran di kelas.

3. Bagi peneliti selanjutnya, disarankan agar dapat mengembangkan penelitian yang lebih baik.

\section{DAFTAR RUJUKAN}

Abdurrahman dan Bintoro. 2000.

Memahami Dan Menangani Siswa

Dengan Problema Belajar. Jakarta :

Depdiknas

Arikunto, Suharsimi. dkk. 2010. Penelitian

Tindakan Kelas. Jakarta: Bumi

Aksara

Djamarah, Syaiful Bahri dan Aswan Zain.

2010. Strategi Belajar Mengajar.

Jakarta: Rineka Cipta.

Hamalik, Oemar. 2013. Proses Belajar

Mengajar. Jakarta: PT.Bumi Aksara

Nur Jatmika, Yusep. (2012). Ragam

Aktivitas Harian untuk TK.

Yogyakarta:

DIVA Press.

Slameto. (2013). Belajar dan faktor-faktor yang mempengaruhi. Jakarta: Rineka Cipta

Sugiyono, (2012), Metode penelitian Kuantitatif, Kualitatif dan R \& D, Penerbit Alfabeta, Bandung 